\title{
Status of medicinal plants in tropical forest of eastern Nepal
}

\author{
Tilak Prasad Gautam \\ Department of Botany \\ Mahendra Morang A.M. Campus, Tribhuvan University, Biratnagar, Nepal \\ E-mail: tilakg673@gmail.com
}

\begin{abstract}
The present study deals with the medicinal properties of 24 species of plants belonging to 23 genera and 17 families found in tropical moist forest of Sunsari district, eastern Nepal. Among them, 5 species of medicinal plants are threatened according to the IUCN categories and Rauvolfia serpentina is included in the appendix II of CITIES.
\end{abstract}

Key words: Ethno-medicine, chemical constituents, Sunsari district, Chaarkoshe jungle, bhabar region.

\section{Introduction}

Humans have used herbal remedies for curing different diseases since prehistoric days. More than 50,000 plants have been used for medicinal purposes throughout the world (Schippmann et al., 2002). According to one estimate, about $80 \%$ of the developing world depends on traditional medicines (Sheldon et al., 1997). Nepal, geographically one of the most diverse countries in the world, has been regarded traditionally as a secret heaven of potent medicinal plants in Vedas, Samhitas and various folk-lores. It may be due to altitudinal variation, complex topography and monsoon climate. From the various studies it has been estimated that about 700 species of plants are used in the Nepalese traditional system of medical treatment. Nepal also earns approximately 22-70 million US\$ from the export of plants annually (Olsen, 1998; 1999).

Tropical forests have played key roles in the livelihood of people residing around them. They are the sources of fresh water and oxygen and provide a diversity of valuable forest products for food and medicine. The continuous exploitation of several medicinal plant species from the wild and substantial loss of their habitats have resulted in population decline of many high value medicinal plant species. The other potential causes for the loss of medicinal plant species are habitat specificity, narrow range of distribution, land use disturbances, introduction of nonnatives, habitat alteration, climatic changes, heavy livestock grazing, explosion of human population, fragmentation and degradation of population.

Some of the species assessed in this study are under the threats. Conservation of heavily exploited tropical forest species is possible by the joint effort of Government and the forest user groups. Endangered species can be conserved if their economic values are recognized. One way to do this is to obtain more basic information not only on the biological and ecological features of the species but also their present and potential uses.

Traditional medicinal knowledge like all other traditional knowledge systems is handed down orally from generation to generation and it may disappear because of rapid socioeconomic, environmental and technological changes. Only solution is that it must be documented and 
conserved through systematic studies before it is lost forever. Therefore, now-a-days, the documentation of indigenous knowledge is receiving much attention. Nepal Biodiversity Strategy has also highlighted the importance for documentation and proper conservation of traditional knowledge and biodiversity (NBS, 2002; CBD, 2009).

\section{Material and Methods}

Study area

The present study was conducted in the tropical moist forest (Charkoshe jungle), located in the bhabar belt of Sunsari district, eastern Nepal (Longitude $86^{\circ} 53^{\prime} \mathrm{E}$ to $87^{\circ} 21^{\prime} \mathrm{E}$ and latitude $26^{\circ} 24^{\prime} \mathrm{N}$ to $26^{\circ} 52^{\prime} \mathrm{N}$ ), within the altitude range of 220 to $370 \mathrm{~m}$ above m.s.l. The climate is tropical monsoon type. The average annual rainfall is $1814.9 \mathrm{~mm}$. Topsoil of the study area is loamy (Gautam \& Mandal, 2012). The forest is dominated by Shorea robusta Gaertn. Other main associates are Lagerstroemia parviflora Roxb., Terminalia alata Heyne ex Roth., Adina cordifolia Benth. \& Hook f. ex Bran, Dillenia pentagyna Roxb., Terminalia bellerica, Croton roxburghii N.P. Balakr. The forest is also the habitat of some rare and commercially as well as medicinally important plants.

The present study was based on a field survey made during 2012-2013 A.D. The survey was conducted among local people, farmers, Dhaami, Jhankri, and vaidyas residing around the forest area to know the local names, place of occurrence and medicinal importance of mentioned plants. The plants with medicinal values were collected and herbarium specimens were made. The identification of plant specimens was done with the help of standard taxonomic literature and also matching with the herbaria, housed in the Post Graduate Campus, Biratnagar. The valid names of the species concerned and their distribution are adopted after Press et al. (2000). The information on the active chemical compounds of mentioned medicinal plants were taken from available literature (Kirtikar \& Basu, 1980; Rastogi \& Mehrotra, 1960-1969; 1970-1979; Satyal et al., 2012).

\section{Results}

The investigation revealed the medicinal properties of 24 species of plants belonging to 23 genera under 17 families. The botanical names, local names, familes, parts used, routes of administration and active chemical compounds are presented in table $1 \& 2$. Fabaceae is the dominant family (4 species), followed by Apocynaceae (3 species), Lamiaceae and Combretaceae ( 2 species each). The other 13 families contributed one species each. Among all the habits, trees are found to be more (14) followed by herbs (6), and shrubs (4). Five species of medicinal plants reported in this study are threatened according to the IUCN categories. Moreover, Rauvolfia serpentina is included in the appendix II of CITIES (Convention on International trade in Endangered Species of Wild Flora and Fauna) list.

Table 1. Medicinal plants found in the tropical forest of eastern Nepal

\begin{tabular}{lllccc}
\hline SN Botanical name (Family) & $\begin{array}{l}\text { Common } \\
\text { name/s }\end{array}$ & Habit & $\begin{array}{l}\text { Distribution } \\
\text { in Nepal (m) }\end{array}$ & $\begin{array}{c}\text { Status } \\
\text { Stat }\end{array}$ \\
\hline 1 & Acacia catechu (L.F.) Willd. (Fabaceae) & Khayer & Tree & $200-1400$ & T \\
2 & Achyranthes aspera L. (Amaranthaceae) & $\begin{array}{l}\text { Datiwan, } \\
\text { Ultekuro }\end{array}$ & Herb & $100-2900$ & - \\
& & & & \\
\hline
\end{tabular}




\begin{tabular}{|c|c|c|c|c|c|}
\hline 3 & Aegle marmelos (L.) Correa (Rutaceae) & Bel & Tree & $60-1000$ & - \\
\hline 4 & Alstonia scholaris (L.) R.Br. (Apocynaceae) & Chaatiwan & Tree & $60-500$ & $\mathrm{R}$ \\
\hline 5 & Asparagus racemosus Willd. (Liliaceae) & Kurilo & Herb & $60-1600$ & - \\
\hline 6 & Bombax ceiba L. (Bombacaceae) & Simal & Tree & $200-900$ & - \\
\hline 7 & Calotropis gigantia (L.) (Asclepediaceae) & Aank & Shrub & $100-1000$ & - \\
\hline 8 & Cassia fistula L. (Fabaceae) & Raajbriksha & Tree & $60-1500$ & - \\
\hline 9 & Colebrookea oppositifolia Sm. (Lamiaceae) & Dhursul & Shrub & $250-1700$ & - \\
\hline 10 & Dalbergia latifolia Roxb. (Fabaceae) & Satisaal & Tree & $300-1000$ & $\mathrm{~V}$ \\
\hline 11 & Eclipta prostata L. (Asteraceae) & Bhringaraaj & Herb & $200-2400$ & - \\
\hline 12 & $\begin{array}{l}\text { Holarrhena pubescence (Buch.-Ham.) ex } \\
\text { G.Don (Apocynaceae) }\end{array}$ & Musabar & Tree & $100-1500$ & - \\
\hline 13 & Hydrocotyl asiatica L.(Apiaceae) & Ghodtapre & Herb & $60-2100$ & - \\
\hline 14 & Mimosa pudica L. (Fabaceae) & Lazawati & Herb & $200-1200$ & - \\
\hline 15 & Oroxylum indicum (L.) Kurz (Bignoniaceae) & Totalo & Tree & $400-1400$ & $\mathrm{~V}$ \\
\hline 16 & Phyllanthus emblica L. (Euphorbiaceae) & Amalaa & Tree & $150-1400$ & - \\
\hline 17 & $\begin{array}{l}\text { Pogostemon benghalensis (Brum. f.) Kuntze } \\
\text { (Lamiaceae) }\end{array}$ & Rudilo & Shrub & $150-1300$ & - \\
\hline 18 & $\begin{array}{l}\text { Rauvolfia serpentina (L.) Benth. ex Kurz } \\
\text { (Apocynaceae) }\end{array}$ & $\begin{array}{l}\text { Sarpagandhaa, } \\
\text { Chandmaruwa }\end{array}$ & Shrub & $150-900$ & $\mathrm{E}$ \\
\hline 19 & Scoparia dulcis L. (Scrophulariaceae) & Mithojhaar & Herb & $100-1200$ & - \\
\hline 20 & Shorea robusta Gaertn. (Dipterocarpaceae) & Sal, Sakhuwa & Tree & $60-1500$ & - \\
\hline 21 & Syzygium cumini (L.) Skeels (Myrtaceae) & Jamunu & Tree & $70-1200$ & - \\
\hline 22 & $\begin{array}{l}\text { Terminalia bellerica (Gaertn.) Roxb. } \\
\text { (Combretaceae) }\end{array}$ & Barro & Tree & $100-1100$ & - \\
\hline 23 & Terminalia chebula Retz. (Combretaceae) & Harro & Tree & $150-1100$ & ـ \\
\hline & Zizyphus mauritiana Lam. (Rhamnaceae) & Bayer & Tree & $200-1200$ & - \\
\hline
\end{tabular}

(IUCN status: $\mathrm{E}=$ endangered, $\mathrm{V}=$ vulnerable, $\mathrm{R}=$ rare, $\mathrm{T}=$ threatened)

Table 2. Medicinal plants with their uses, parts used routes of administration and active chemicals.

\begin{tabular}{|c|c|c|c|c|}
\hline $\begin{array}{l}\text { Ailments } \\
\text { Botanical name }\end{array}$ & Part(s) used & $\begin{array}{l}\text { Form of } \\
\text { use }\end{array}$ & Routes & Active constituents \\
\hline \multicolumn{5}{|l|}{ Removal of dead foetus } \\
\hline Achyranthes aspera & Whole plant & Decoction & Oral & $\begin{array}{l}\text { Betaine, ecdysone, } \\
\text { ecdysterone, oleanolic acid. }\end{array}$ \\
\hline \multicolumn{5}{|l|}{ Snake and scorpion bite } \\
\hline Achyranthes aspera & Root & Paste & Topical & - \\
\hline Hydrocotyl asiatica & Whole plant & Decoction & Oral & - \\
\hline \multicolumn{5}{|l|}{ Diarrhoea and dysentery } \\
\hline Aegle marmelos & Unripe fruit & Pulp & Oral & Marmin, ageline, marmesin. \\
\hline Bombax ceiba & Stem & Latex & Oral & Arabinose, galactose etc. \\
\hline Dalbergia latifolia & Stem & Latex & Oral & - \\
\hline Holarrhena pubescence & Stem bark & Decoction & Oral & Conessine, norconessine \\
\hline Mimosa pudica & Root & Paste & Oral & - \\
\hline Oroxylum indicum & Stem bark & Decoction & Oral & Oroxylin A, chrysin etc. \\
\hline Pogostemon benghalensis & Leaf & Decoction & Oral & $\begin{array}{l}\text { Essential oils like terpinene, } \\
\text { caryophyllene, cardinene. }\end{array}$ \\
\hline Shorea robusta & Stem bark, resin & Decoction & Oral & $\begin{array}{l}\text { Corilagin, ellagic, gallic, } \\
\text { shorbic acids etc. }\end{array}$ \\
\hline
\end{tabular}




\begin{tabular}{|c|c|c|c|c|}
\hline Terminalia bellerica & Fruit & Powder & Oral & - \\
\hline \multicolumn{5}{|l|}{ Lactation } \\
\hline Asparagus racemosus & Root & Decoction & Oral & - \\
\hline \multicolumn{5}{|l|}{ Diabetes } \\
\hline Aegle marmelos & Leaf & Powder & Oral & Limonene, $\beta$-ocimene etc. \\
\hline Asparagus racemosus & Leaf & Infusion & Oral & Quercetin-3- glucunoride. \\
\hline Syzygium cumini & Seed & Decoction & Oral & - \\
\hline \multicolumn{5}{|l|}{ Tonic } \\
\hline Asparagus racemosus & Root & Decoction & Oral & - \\
\hline \multicolumn{5}{|l|}{ Sprains } \\
\hline Calotropis gigantia & Stem & Latex & Topical & - \\
\hline \multicolumn{5}{|l|}{ Diuretic } \\
\hline Cassia fistula & Fruit & Pulp & Oral & Glucose, sucrose, fructose \\
\hline Scoparia dulcis & Leaf & Decoction & Oral & - \\
\hline \multicolumn{5}{|l|}{ Cuts and wounds } \\
\hline Colebrookea oppositifolia & Leaf & Latex & Topical & - \\
\hline Eclipta prostata & Leaf & Latex & Topical & Polyacetylenic thiophenes. \\
\hline Hydrocotyl asiatica & Leaf & Latex & Topical & - \\
\hline \multicolumn{5}{|l|}{ Leprosy } \\
\hline Dalbergia latifolia & Stem bark & Decoction & Oral & - \\
\hline \multicolumn{5}{|l|}{ Anthelmintic } \\
\hline Acacia catechu & Stem bark & Decoction & Oral & - \\
\hline Holarrhena pubescence & Seed & Decoction & Oral & - \\
\hline $\begin{array}{l}\text { Improve memory power } \\
\text { Hydrocotyl asiatica }\end{array}$ & \multicolumn{3}{|c|}{ Improve memory power } & Brahmic, thankunic acids \\
\hline \multicolumn{5}{|l|}{ Syphilis } \\
\hline \multicolumn{5}{|l|}{ Burns and boils } \\
\hline \multicolumn{5}{|l|}{ Gastric troubles } \\
\hline Phyllanthus emblica & Stem bark & Decoction & Oral & $\begin{array}{l}\text { Tannin, lelucodelphinidin, } \\
\text { procyanidin, prodelphinidin }\end{array}$ \\
\hline \multicolumn{5}{|l|}{ Scabies and ringworms } \\
\hline \multicolumn{5}{|l|}{ Fever } \\
\hline Alstonia scholaris & Bark & Decoction & Oral & $\mathrm{HCl}$ of echitamine \\
\hline Rauvolfia serpentina & Stem, root, leaf & Decoction & Oral & $\begin{array}{l}\text { Alkaloids: reserpine, } \\
\text { ajmaline, serpentine in root. }\end{array}$ \\
\hline \multicolumn{5}{|l|}{ Sedative and hypnotic } \\
\hline \multicolumn{5}{|l|}{ Measles } \\
\hline Zizyphus mauritiana & Root, seed & $\begin{array}{l}\text { Decoction, } \\
\text { ash (Seed) }\end{array}$ & $\begin{array}{l}\text { Topica, } \\
\text { oral }\end{array}$ & $\begin{array}{l}\text { Alkaloids hysodricanine A, } \\
\text { mauritine } \mathrm{H} \text {, yuziphine etc. }\end{array}$ \\
\hline \multicolumn{5}{|l|}{$\begin{array}{l}\text { Tonsil } \\
\end{array}$} \\
\hline Scoparia dulcis & Leaf & Latex & Oral & - \\
\hline \multicolumn{5}{|l|}{ Cough } \\
\hline Terminalia chebula & Fruit & Decoction & Oral & - \\
\hline
\end{tabular}


These plants are being used in 20 ailments (Fig. 1). The major ailments on the basis of number of species used are diarrhoea and dysentery (9 species); diabetes and cuts plus wounds (3 species each).

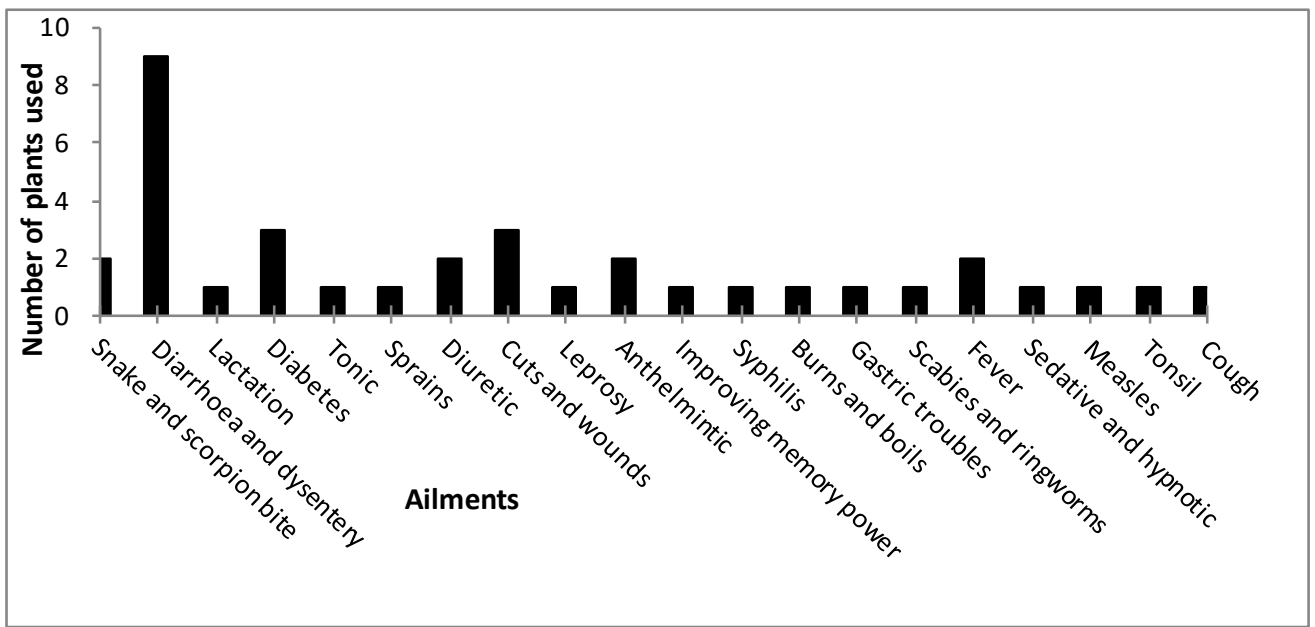

Figure 1. Different ailments and number of plants used in the surrounding of tropical forest, eastern Nepal.

The most frequently used medicines are derived from stems and barks (31\%), followed by leaves $(25 \%)$, roots $(18 \%)$, fruits $(10 \%)$, seeds $(8 \%)$ and whole plants $(8 \%)$ (Fig. 2). The maximum use of stem and barks indicates that these parts may have strong medicinal properties. Among the dosage forms, the most frequently used dosage was decoction $(61 \%)$ followed by latex (juice) $(27 \%)$, powder (6\%), and paste (6\%) (Fig. 3). The routes of administration were oral (76\%) and topical (24\%) (Table 2).

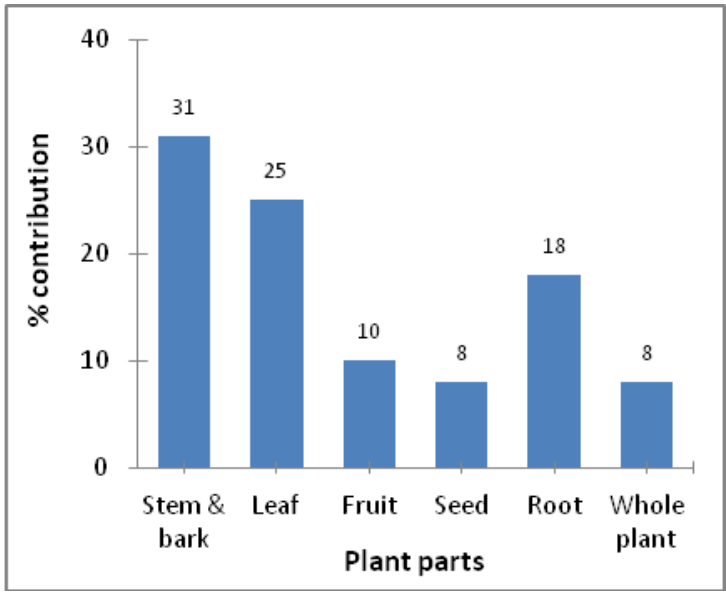

Figure 2. Plant parts and their $\%$ contribution.

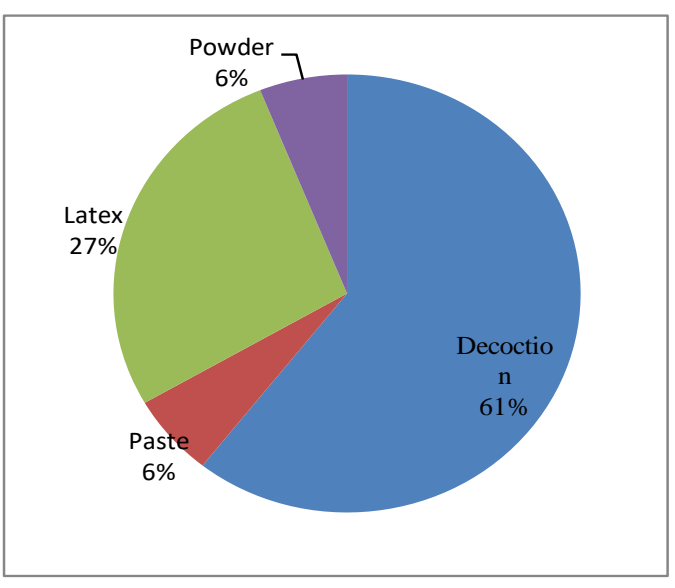

Figure 3. Forms of use of medicinal plants. 


\section{Discussion}

This study revealed that the use of medicinal plants differs not only from region to region but also among and within communities. For example, Achyranthes aspera was used in two different ailments (for the removal of dead foetus and snake and scorpion bites) at two places. It may be due to the difference in the active alkaloids or steroids in the same plant growing in different habitats. The second possibility may be that the plant possesses that activity but that this beneficial therapeutic effect has just not been discovered. In spite of this, few such examples were met that some plants were used for the same purpose in different regions.

The local people residing around the forest area used some medicinal plant species as a source of food, fodder, timber as well as various other ethnobotanical purposes. For example, apart from the use of Aegle marmelos, Syzygium cumini, Phyllanthus emblica, Zizyphus mauritiana and Terminalia bellirica as medicines, the fruits of these species are edible, the leaves of some species are used for fodder and the wood is used for fuel. Some species like Aegle marmelos and Oroxylum indicum are used for medicinal as well as religious purposes by the Hindus. The Buddhist community regards Terminalia chebula as an important medicine as well as sacred fruit. Shorea robusta and Dalbergia latifolia are not only the sources of medicine but also used as valuable and high priced timber.

The present study showed that, the older persons have greater knowledge regarding the utilization of medicinal plants in comparison to younger generation. Same result was also observed by previous workers (Acharya \& Acharya, 2010; Gautam, 2011). It might be due to poor recognition of traditional healers and availability of modern health facilities. However, strong emphasis should be given for the documentation of indigenous uses, traditional knowledge and practices before their loss. The present and past studies showed that the plant medicines are less suitable to control and treat epidemic and endemic infectious diseases and acute life-threatening infections. For these problems, modern drugs might be the best choice. But for common diseases such as colds, skin diseases, worms, wounds etc. medicinal plants are the best alternatives to costly imported drugs.

\section{Conclusions}

The tropical forests are the potential sources of medicinal plants. But they are under destruction due to human activities, climate change etc. The sustainable use of the medicinal plants will certainly improve the economic condition of this region. The traditional knowledge of the forest plants should be documented before their loss. But the indigenous practices need to be validated before they can be widely promoted. They can be the starting point for drug and technology development. Proper conservation, management and utilization of medicinal plants also help to maintain biodiversity. Furthermore, a detail survey should be carried out by the government to assess the status of medicinal plants in the tropical forests of Nepal.

\section{Acknowledgments}

Author is grateful to the Head, Department of Botany, Post Graduate Campus Biratnagar, for providing herbarium facilities during plant identification. Author also likes to extend his gratitude to the local healers and tribal people for providing information on the medicinal plants. 


\section{References}

Acharya, K.P. \& M. Acharya. 2010. Traditional knowledge on medicinal plants used for the treatment of livestock diseases in Sirdikhola VDC, Kaski, Nepal. Journal of Mediicnal Plants Resources 4: 235-239.

CBD, 2009. Nepal fourth National report to the Convention on Biological diversity. Ministry of Forests and Soil Conservation, Nepal Government, Nepal. pp. 180.

Gautam, T.P. \& T.N. Mandal. 2012. Effect of disturbance on fine root biomass in the Tropical moist forest of eastern Nepal. Nepalese Journal of Biosciences 2: 10-16.

Gautam, T.P. 2011. Indigenous uses of some medicinal plants in Panchthar district, Nepal. Nepalese Journal of Biosciences 1: 125-130.

Kirtikar, K.R. \& B.D. Basu 1980. Indian Medicinal Plants. Dehradun: Bishensingh \& Mahendrapal Singh.

NBS, 2002. Nepal Biodiversity Strategy. Ministry of Forests and Soil Conservation, Nepal Government, Nepal. pp. 117.

Olsen, C.S. 1998. The trade in medicinal plants from Nepal: status and possible improvements. Theme paper presented at the International Conference on Medicinal Plants, Banglore, 16-19 February, 1998.

Olsen, C.S. 1999. CITES Appendix II revisited: is the listing of Nardostachys grandiflora and Picrorhiza kurroora appropriate. Medicinal Plant Conservation 5: 8-10.

Press, J.R., K.K. Shrestha \& D.A. Sutton. 2000. Annonated checklist of the flowering plants of Nepal. The Natural History Museum, London, U.K. pp. 430.

Rastogi, R.P. \& B.N. Mehrotra. 1960-1969. Compendium of Indian Medicinal Plants, Vol. 1, Central Drug Research Institute, Lucknow and Publication and Information Directorate, New Delhi, pp. 497.

Rastogi, R.P. \& B.N. Mehrotra. 1970-1979. Compendium of Indian Medicinal Plants, Vol. 2, Central Drug Research Institute, Lucknow and Publication and Information Directorate, New Delhi, pp. 859.

Satyal, P., K.E. Woods, N.S. Dosoky, S. Neupane \& W.N. Setzer. 2012. Biological Activities and Volatile Constituents of Aegle marmelos (L.) Correa from Nepal. Journal of Medicinally Active Plants 1(3): 114-122. Available at: http://scholarworks.umass.edu/jmap/vol 1/iss3/6.

Schippmann U., D.J. Leaman, A.B. Cunninghan. 2002. Impact of cultivation and gathering of medicinal plants on Biodiversity: FAO, Biodiversity and the Ecosystem Approach in Agriculture, Forestry and Fisheries. Satellite event on the occasion of the Ninth Regular Session of the Commission on Genetic Resources for Food and Agriculture. Rome, InterDepartmental Working Group on Biological Diversity for Food and Agric. Rome. pp. 12-13.

Sheldon, J.W., M.J. Black \& S. Laird. 1997. Medicinal plants: can utilization and conservation coexist? Scientific Publications, The New York Botanical Garden, USA pp. 104. 